AGRICULTURE AND BIOLOGY JOURNAL OF NORTH AMERICA

ISSN Print: 2151-7517, ISSN Online: 2151-7525, doi:10.5251/abjna.2011.2.6.952.963

(C) 2011, ScienceHu $\beta$, http://www.scihub.org/ABJNA

\title{
Physico-chemical changes during growth and development of 'Galia' cantaloupes. II. Chemical changes
}

\section{Abu-Bakr Ali Abu-Goukh, Al Fadil Mohamed Baraka and Mustafa Mohamed Ali Elballa}

\author{
Department of Horticulture, Faculty of Agriculture, University of Khartoum, \\ Shambat 13314, Sudan \\ Corresponding author: Abu-Bakr Ali Abu-Goukh, phone number +249912148700,
}

E-mail: aabugoukh@uofk.edu; aabugoukh@yahoo.com.

\begin{abstract}
Chemical changes during growth and development of fruits of three 'Galia' melon cultivars were evaluated. The respiration curves of the three cultivars exhibited a typical climacteric pattern, with peak of respiration coinciding with full maturity (44 DAA) and then decreased. Fruit flesh firmness slightly decreased up to the mature-green stage and then sharply declined during the ripening phase (44-48 DAA). Rind color, total soluble solids (TSS) and total sugars progressively increased during growth and development of the three cultivars. Reducing sugars and titratable acidity progressively increased, reaching a peak at 42 DAA and subsequently decreased. Total protein and ascorbic acid content increased steadily in the three cultivars, reaching a peak at 44 DAA, which coincided with the climacteric peak of respiration and then declined. Phenolic compounds progressively decreased with growth and development in the three cultivars. Galia cantaloupes should be harvested at least at physiological maturity, where the fruit attains maximum size and weight, rind color develops, TSS reaches $10 \%$, total sugars above $8 \%$, proteins and ascorbic acid at maximum levels, titratable acidity starts to decrease, phenolics are reasonably low and the fruit is still firm.
\end{abstract}

Keywords: Galia cantaloupes; chemical changes; growth and development.

\section{INTRODUCTION}

Cantaloupe (Cucumis melo L.) is an important vegetable crop grown worldwide. It is used as a dessert or breakfast fruit and often used in fruit salads, bunches and jellied meals. The fruit contains $0.7 \mathrm{~g}$ protein, $0.1 \mathrm{~g}$ fat, $7.5 \mathrm{~g}$ carbohydrate, $0.3 \mathrm{~g}$ fiber, $0.5 \mathrm{~g}$ ash, $14 \mathrm{mg}$ calcium, $16 \mathrm{mg}$ phosphorus, $0.4 \mathrm{mg}$ ion, $12 \mathrm{mg}$ sodium, $251 \mathrm{mg}$ potassium, $3400 \mathrm{IU}$ vitamin A and $33 \mathrm{mg}$ ascorbic acid per $100 \mathrm{~g}$ of fresh weight (Watt and Merrill, 1975).

Cantaloupes rank second after mango in Sudanese horticultural exports in term of revenue (AOAD 2008). 'Galia' is the only melon cultivar grown for export in Sudan (Baraka, 2004). Although Sudan has great potential to produce and export high quality cantaloupes, the harvesting and post-harvest practices are still not taken care of by both producers and distributors. These practices need a lot of improvement for the development of a sound cantaloupe industry. During the last few years, farmers failed to harvest and keep their product to comply with export requirements. About $40 \%$ to $55 \%$ of total yield is classified as local market grade
(Abbas, 2004). This is mainly attributed to smooth or incomplete netted fruits. Although fruits in this grade meet the specification required for export in terms of weight and shape, but have low quality grade with respect to sugar content and flavor. Importers feedback indicated that considerable part of the product was discarded at destination for poor quality, due to improper harvesting maturity and handling practices (MACK, 1999; Rustenburg Co., 1999).

Correct harvest maturity of cantaloupe is rather difficult to determine. As the melon approaches maturity, the netting becomes fully rounded out and rind color changes. As ripening advances, a crack develops around the peduncle at the base of the fruit and when fully ripe, the fruit slips easily from the stem, leaving a large scar. The total soluble solids, refractive index, sucrose content of fruit juice increase and the percentage of starch in the fruit decreases as the melon ripens (Salunkhe and Desai, 1984). Mutton et al. (1981) suggested that a practical grade standard might be $10 \%$ minimum solids with upper and lower limits for flesh firmness of 2.0 and $1.0 \mathrm{~kg}$ per $\mathrm{cm}^{2}$, respectively. Most cantaloupes are 
commercially harvested when half of the stems separated from the melon (half-slip) (Kasmire et al., 1970). Abscission zone development often corresponds to a change from green to yellow in rind color. If picked at proper maturity, cantaloupes will continue to soften and become more aromatic after harvest (Ayub et al., 1996). Changes in the total soluble solids, total sugar, total volatiles, $\mathrm{pH}$, some amino acids and some minerals were strongly correlated. These changes were related to metabolic activity during fruit growth and maturation (Wang, 1990). Harvesting maturity usually requires a combination of these chemical and physical parameters, coupled with considerable experience (Saunkhe and Desai, 1984). In a previous study, Baraka et al. (2010) evaluated the physical parameters and found that the fruits of the three cultivars reached physiological maturity after 44 days from anthesis (DAA) and the ripening phase was (4448 DAA).

This study was carried out to evaluate the chemical changes during growth and development of 'Galia' cantaloupes, to provide base-line information regarding the biochemistry of the developing fruit and to assist in the selection of the right harvesting maturity.

\section{MATERIALS AND METHODS}

Experimental Site and Cultural Practices: A field experiment was conducted at Silate Agricultural Project-Khartoum North, during the winter season. Land preparation and cultural practices were carried out as described earlier (Baraka et al., 2010).

Experimental Material: Hundred and sixty plants were selected randomly in each of the plots for fruit sampling. Fruits were tagged at time of flowering on each selected plant. Fruits were picked at 12, 19, 26, $33,40,42,44,46$ and 48 days after anthesis (DAA) for determination of chemical changes during growth and development of the fruit. Ten fruits were picked at random from each replicate of the three 'Galia' cultivars at the designated time for the determination of respiration rate, total soluble solids, total and reducing sugars, titratable acidity, total protein, phenolic compounds and ascorbic acid content.

Parameters Studied: Respiration rate was determined by the total absorption method and was expressed in $\mathrm{mg} \mathrm{CO}_{2}$ per kilogram per hour (Mohamed-Nour and Abu-Goukh, 2010). Total soluble solids (TSS) were determined for the fruit juice extracted by pressing the fruit pulp in a garlic press using a Kruss hand refractometer (model HRN-
32). Two readings were taken from opposite sides of each fruit and mean values were calculated and corrected according to the refractometer chart.

Thirty grams of pulp of the fruit picked at the designated time of each of the three 'Galia' hybrids were minced and homogenized in $100 \mathrm{ml}$ of distilled water for one minute in an electric blender and centrifuged at $10,000 \mathrm{rpm}$ for 10 minutes in a Gallenkamp portable centrifuge (CF 400). The volume of the supernatant, which constitutes the pulp extract, was determined. Total and reducing sugars were determined in the pulp extracts of the three 'Galia' hybrids. Total sugars were determined according to the anthrone method of Yemm and Willis (1954). Reducing sugars were measured according to the technique described by Somogyi (1952). Total and reducing sugars were expressed in grams per 100 grams fresh weight.

Titratable acidity was measured in the pulp extracts of the three 'Galia' hybrids according to the method described by Ranganna (1979) and was expressed as percent citric acid. Total protein was determined in pulp extracts by the protein dye-binding method of Bradford (1976) and was expressed in grams per 100 grams fresh weight. Total phenolic compounds were determined in the pulp extracts of the three 'Galia' hybrids by the Folin-Ciocalteu method (Singleton and Rossi, 1965) and were expressed in milligrams per 100 grams fresh weight. Ascorbic acid content was determined for the pulp extract of the three 'Galia' hybrids using the 2,6-dichlorophenol-indophenol titration method of Ruck (1963). Ascorbic acid content was expressed in milligrams per 100 grams fresh weight.

Statistical Analysis: Analysis of variance and Fisher's protected LSD test with a significance level of $\mathrm{P} \leq 0.05$ were performed on the data (Gomez and Gomez, 1984).

\section{RESULTS AND DISCUSSION}

The three 'Galia' cultivars were significantly different in all parameters studied. 'Standard Galia' and 'MN318' were closely related and quite different from 'Solar King' in most parameters. The two cultivars were lower in respiration rate, TSS, total and reducing sugars, and higher in ascorbic acid content, compared to 'Solar King'. 'MN-318' and 'Solar King' were close to each other and significantly higher in titratable acidity, total protein and phenolic compounds, compared to 'Standard Galia'. Similar variation among cultivars was reported during growth and development in mango (Abu-Goukh et al., 2005), 
papaya (Abu-Goukh et al., 2010) and during ripening in guava (Bashir and Abu-Goukh, 2003) and tomato (Ahmed and Abu-Goukh, 2003).

Respiration Rate: The respiration rate curves of the three 'Galia' cultivars exhibited a typical climacteric pattern. This is in agreement with the findings of Kitamura et al. (1975). Kader (2002) reported that cantaloupes have a moderate rate of respiration of 10 to $20 \mathrm{mg} \mathrm{CO} / \mathrm{kg}-\mathrm{hr}$ at $5^{\circ} \mathrm{C}$ and a respiratory climacteric was observed with fruit ripening. The respiration rate progressively increased from 12 days after anthesis (DAA), reached a peak at 44 DAA and then declined in the three cantaloupe cultivars (Fig. 1). 'Solar King $F_{1}$ ' had significantly the highest respiration rate during growth and development with peak of $126 \mathrm{mg} \mathrm{CO} / \mathrm{kg}$-hr. 'Standard' and 'MN-318' exhibited almost similar respiration rates during fruit growth and development with peaks of 90 and $86 \mathrm{mg}$ $\mathrm{CO}_{2} / \mathrm{kg}$-hr, respectively (Fig. 1 ).

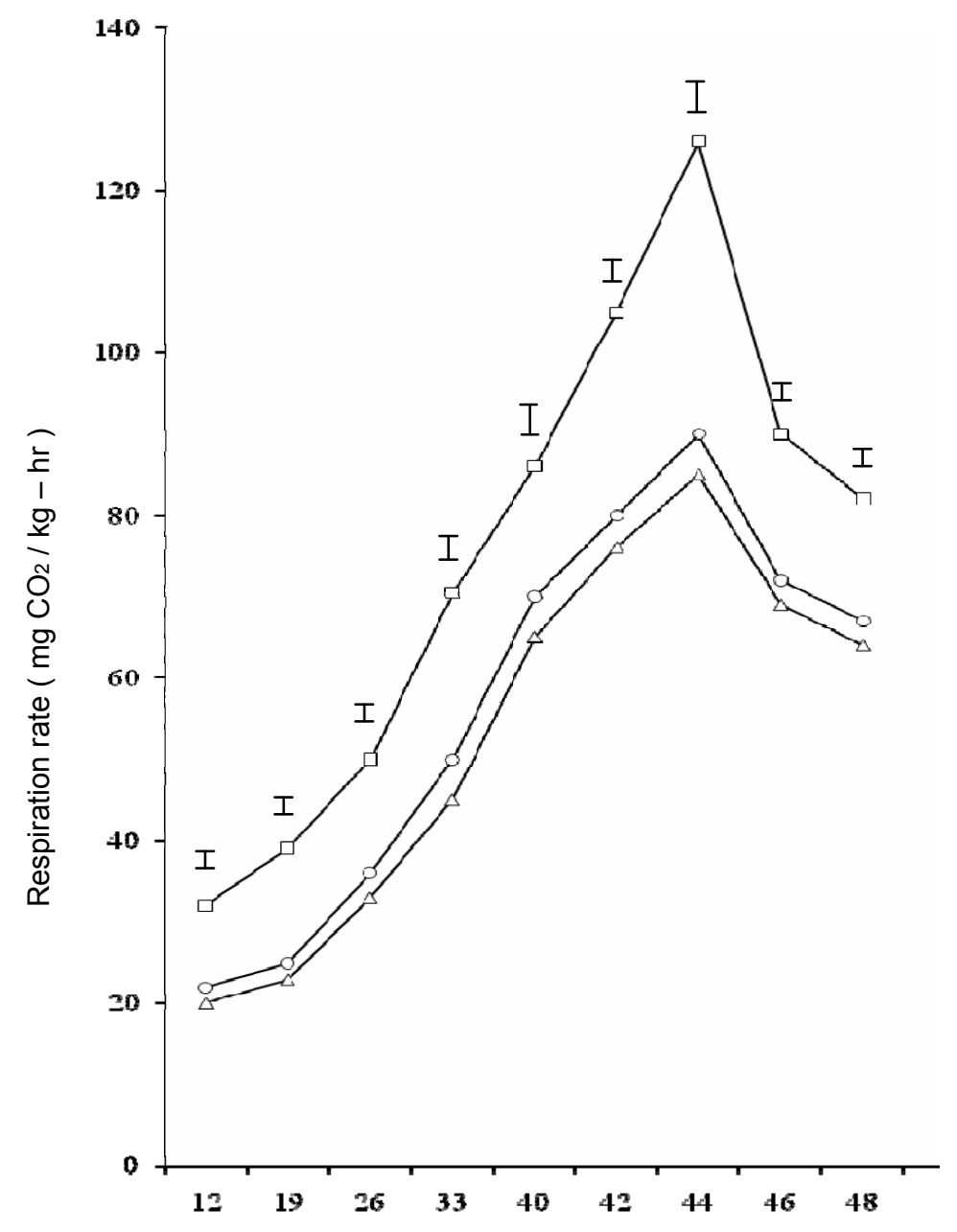

Days after anthesis

Fig. 1. Changes in respiration rate during growth and development of 'Galia $F_{1}$ Standard' ( $(\circ)$, 'Galia $F_{1}$ MN-318' $(\Delta)$, and 'Galia $F_{1}$ Solar King' ( $\square$ ) cantaloupe cultivars. Vertical bars represent LSD (5\%). 
Agric. Biol. J. N. Am., 2011, 2(6): 952-963

Total Soluble Solids: Total soluble solids (TSS) progressively increased during growth and development of the three 'Galia' cantaloupe cultivars (Fig.2). Maximum TSS values reached at the full ripe stage (48 DAA), were $11.5 \%, 11.9 \%$ and $12.6 \%$ in the 'Standard', 'MN-318' and 'Solar King', respectively. That increase was 3.2-, 3.6- and 3.8folds in 'Standard', 'MN-318' and 'Solar King' cultivars, respectively. Similar trends were reported in mango (Abu-Goukh et al., 2005), banana (Osman and Abu-Goukh, 2008), guava (Bashir and AbuGoukh, 2003), papaya (Abu-Goukh et al., 2010), and tomato (Ahmed and Abu-Goukh, 2003). These data are in agreement with Albuquerque et al. (2006), who reported that sugars started to accumulate in cantaloupes 32 days after flowering, and continued until maturity. Mutton et al. (1981) set TSS of $10 \%$ at harvest as minimum quality grade standard for 'Rocket' melon cultivar in USA.

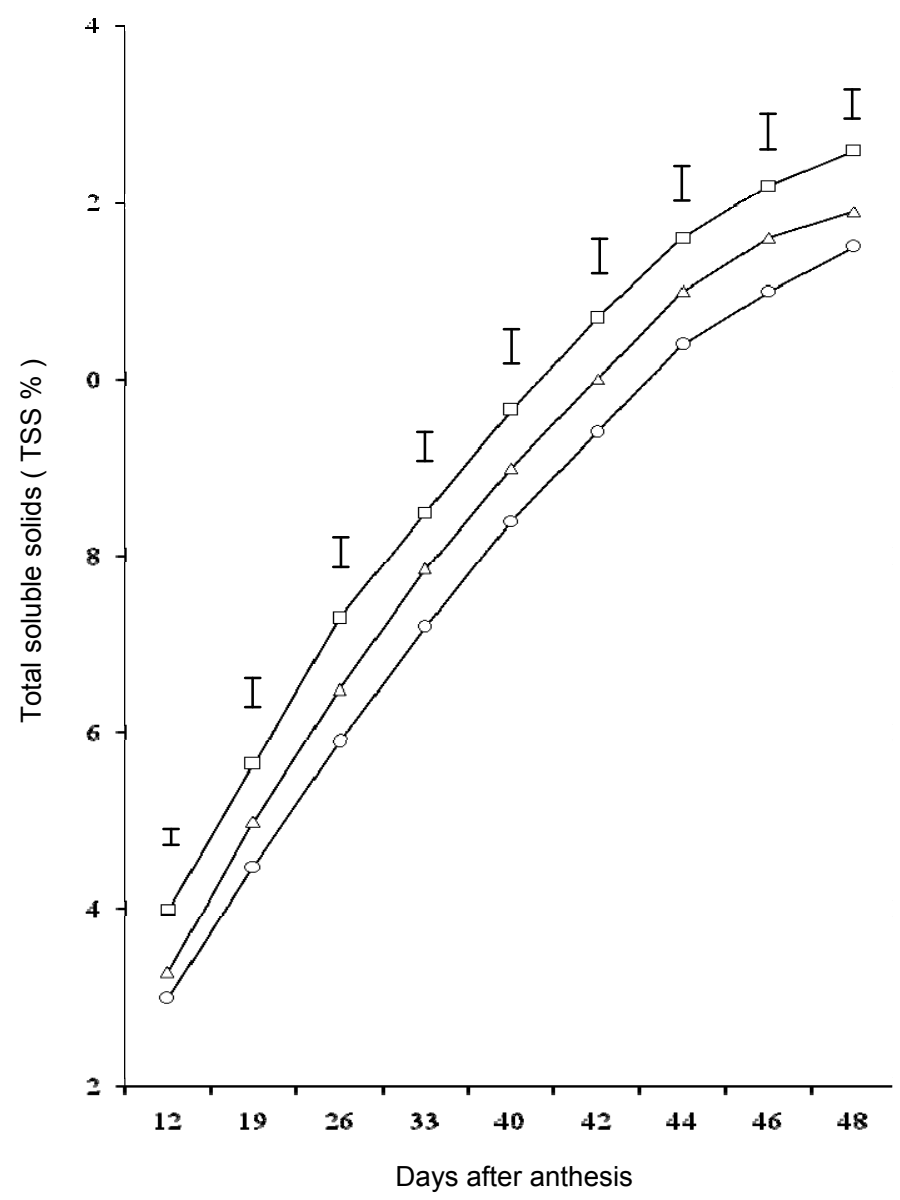

Fig. 2. Changes in total soluble solids during growth and development of 'Galia $F_{1}$ Standard' $(\circ)$, 'Galia $F_{1}$ MN-318' $(\Delta)$, and 'Galia $F_{1}$ Solar King' ( $\square$ ) cantaloupe cultivars. Vertical bars represent LSD (5\%). 
Total and Reducing Sugars: The trend of changes in total sugars during growth and development of the three cantaloupe cultivars (Fig.3) was similar to that of total soluble solids (TSS) (Fig. 2). This is in agreement with previous reports that sugars accumulation during growth and development of cantaloupes was closely correlated with TSS and other quality attributes (Aulenbach et al., 1974). Similar results were reported in banana (Ibrahim et al., 1994), mango (Abu-Goukh et al., 2005) and guava (Bashir and Abu-Goukh, 2003). According to Bianco and Pratt (1977), 97\% of TSS of cantaloupe fruits is soluble sugars, with sucrose accounting for $50 \%$ of the total sugars.

Total sugars increased dramatically during growth and development of the three cultivars up to the mature-green stage (44 DAA) and then flattened (Fig. 3). 'Solar King' scored the highest total sugars (9.1mg/100g), followed by 'Standard' $(8.5 \mathrm{mg} / 100 \mathrm{~g})$ and then 'MN-318' $(8.1 \mathrm{mg} / 100 \mathrm{~g})$, at the full ripe stage (48 DAA). These results are in line with previous reports that sucrose is the principal sugar in cantaloupes, absent in young fruits, but showing dramatic increase during ripening (Villanueva et al., 2004). Typical full-slip was reported to be about 42 DAA in most cantaloupe cultivars (Agblor and Waterer, 2001). At that stage the cantaloupe fruit has achieved its maximum sugar development (Miller, 2007). Sugar accumulation is a very important physiological process that determines dessert-melon fruits quality (Stepansky et al., 1999) and 10\% solids was proposed as a minimum quality grade standard for cantaloupes with upper and lower limits of flesh firmness of 2.0 and $1.0 \mathrm{~kg} / \mathrm{cm}^{2}$, respectively (Mutton et al., 1981).

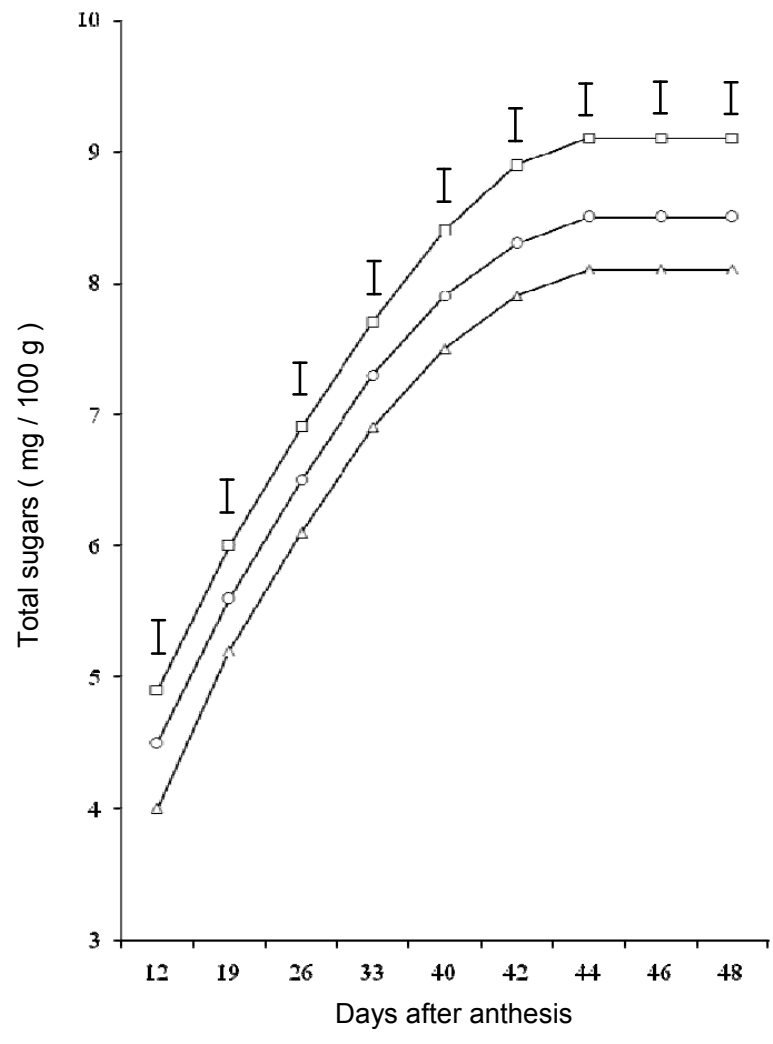

Fig. 3. Changes in total sugars during growth and development of 'Galia $F_{1}$ Standard' (०), 'Galia $F_{1}$ MN-318' $(\Delta)$, and 'Galia $F_{1}$ Solar King' ( $\left.\square\right)$ cantaloupe cultivars. Vertical bars represent LSD (5\%). 
Reducing sugars progressively increased, reaching a peak at 42 DAA, in the three cantaloupe cultivars and subsequently decreased thereafter (Fig.4). This is in agreement with the findings of Bianco (1969). Similar patterns of reducing sugar changes were reported in mango (Abu-Goukh et al., 2005), guava (Bashir and Abu-Goukh, 2003) and papaya (Abu-Goukh et al., 2010). Bianco (1969) reported that glucose and fructose contents progressively increased up to the mature-green stage and decreased afterwards.
Mutton et al. (1981) found that fructose and glucose contents were relatively constant, but fructose accumulation was rapidly increased four weeks after anthesis. Climacteric fruits in particular, may show considerable changes in sugars contents during fruit ripening (Hulme, 1971). During ripening starch and sucrose are converted to glucose (Wills et al. 1998), which is the main substrate utilized in respiration (Phan et al., 1975).

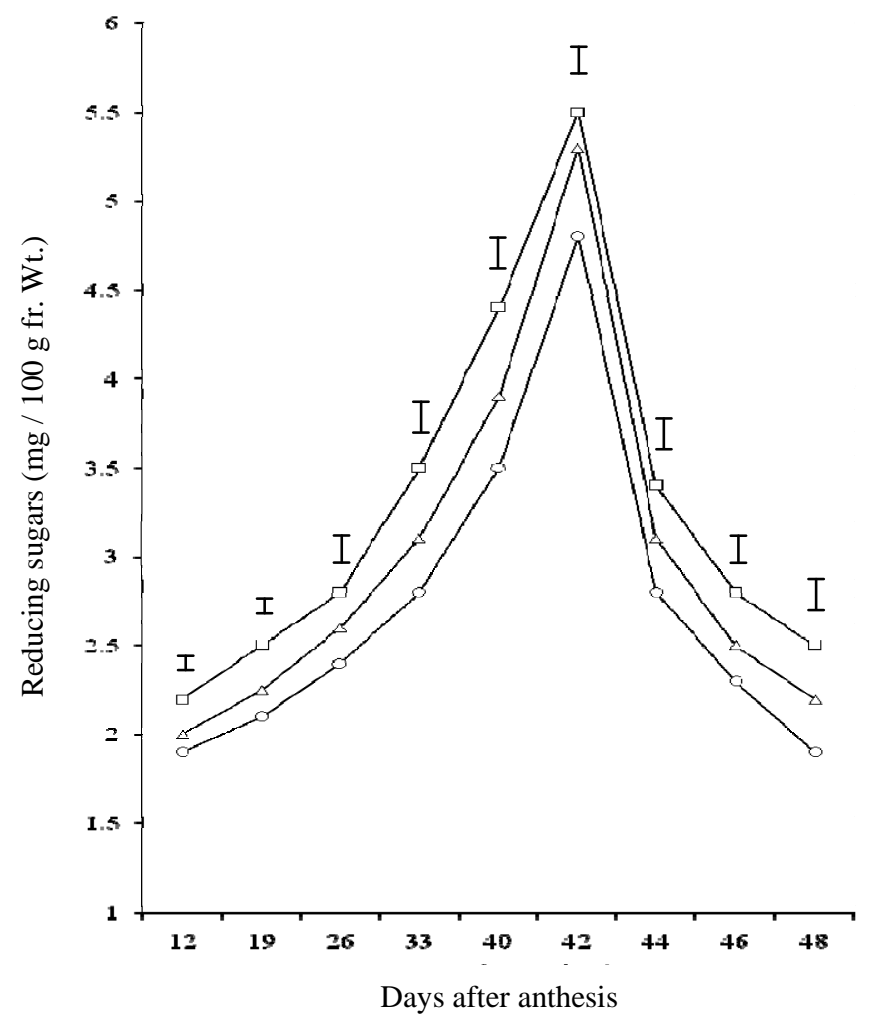

Fig. 4. Changes in reducing sugars during growth and development of 'Galia $F_{1}$ Standard'

$(\circ)$, 'Galia $F_{1}$ MN-318' $(\Delta)$, and 'Galia $F_{1}$ Solar King' $(\square)$ cantaloupe cultivars.

Vertical bars represent LSD (5\%).

Titratable Acidity: Titratable acidity progressively increased during growth and development of the three cantaloupe cultivars reaching a peak at 42 days after anthesis and decreased afterwards (Fig. 5). Mattoo et al. (1975) reported that the non-volatile organic acids are among the major cellular constituent's under-going changes during fruit ripening. Similar patterns were reported during growth and development of mango (Abu-Goukh et al., 2005) and papaya (Abu-Goukh et al., 2010) and 
during ripening and storage of banana (Munasque and Mendoza, 1991), guava (Bashir and Abu-Goukh, 2003), and tomato (Ahmed and Abu-Goukh, 2003). Galia 'MN-318' was highest in titratable acidity with peak of $0.55 \%$ (citric acid), followed by 'Solar King' with peak of $0.53 \%$ and then 'Standard' with peak of $0.48 \%$ (Fig.5).

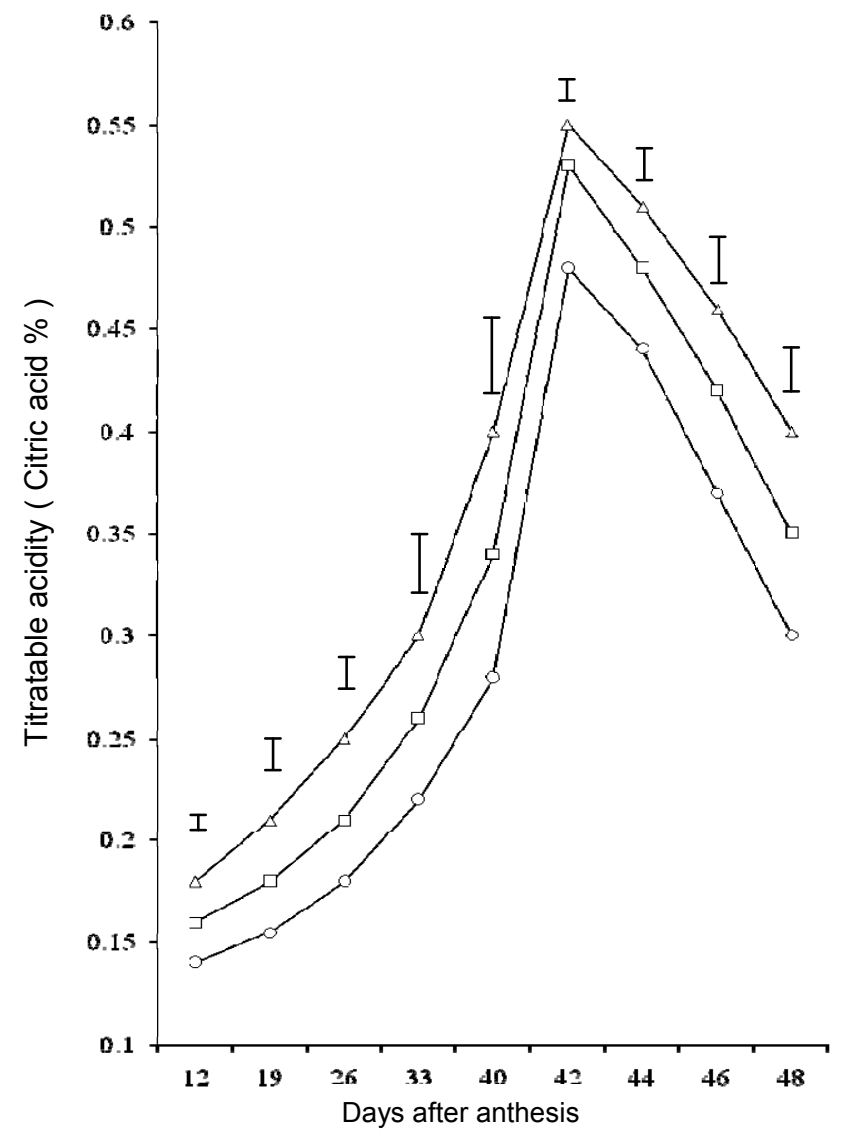

Fig. 5. Changes in titratable acidity during growth and development of 'Galia $F_{1}$ Standard' $(\circ)$, 'Galia $F_{1}$ MN-318' $(\Delta)$, and 'Galia $F_{1}$ Solar King' ( $\square$ ) cantaloupe cultivars. Vertical bars represent LSD $(5 \%)$.

These results support the view that acids can be used as substrates for respiration when sugars have been consumed or participated in the synthesis of lipids and volatile aromas and provide in addition, a series of metabolites which are used in many processes that reflect dominance of sweet flavor in cantaloupes (Ulrich, 1970).

Total Proteins: Total proteins increased steadily to reach a peak at 44 DAA and then declined in the three cultivars (Fig.6). 'MN-318' showed the highest 
total proteins peak $(516 \mathrm{mg} / 100 \mathrm{~g})$, followed by 'Solar King' (490 mg), and then 'Standard' (440 mg). The increase in total proteins during the ripening process was 2.5-, 2.6- and 2.7- folds in 'MN-318', 'Standard' and 'Solar King' cultivars, respectively. These results are in agreement with Villanueva et al. (2004) who found that proteins increased with ripening in cantaloupe, while pectins decreased continuously during ripening. Similar results were reported during growth and development of mango (Abu-Goukh et al., 2005) and papaya (Abu-Goukh et al., 2010).

Although proteins are minor constituents of fruits and vegetables and have no clear role in determining eating quality, changes in their contents indicate variation in metabolic activity during the development of the fruit (Wills et al., 1998). The increase in protein content during the pre-climacteric phase indicates an increase in protein synthesis and the decline during the post-climacteric phase reflects breakdown of proteins during senescence. This support the view that proteins in ripening fruits are enzymes required for the ripening process (Frenkel et al., 1968). The increase in proteins content during the climacteric phase coincided with increased activity of polygalacturonase, pectinesterase and cellulase enzymes with high correlation between the increase in enzyme activity and loss of fruit flesh firmness in mango (Abu-Sarra and Abu-Goukh, 1992), guava (Abu-Goukh and Bashir, 2003), pear (Ahmed and Labavitch, 1980) and tomato (Ali and Abu-Goukh, 2005).

The decline in proteins content at the over-ripe stage was explained as breakdown of proteins during senescence, which again supports the view that proteins in ripening fruits are mainly enzymes required for the ripening process (Frenkel et al., 1968; Abu-Goukh and Bashir, 2003; Ali and AbuGoukh, 2005).

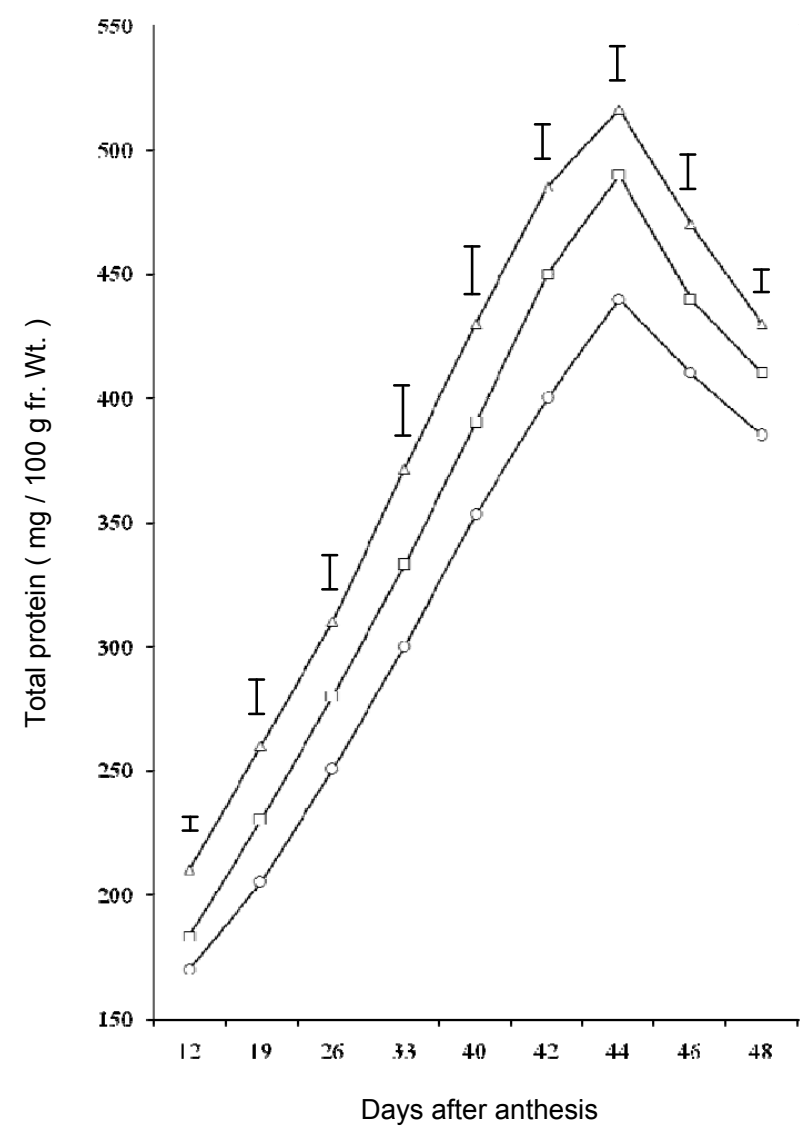

Fig. 6. Changes in total protein during growth and development of 'Galia $F_{1}$ Standard' ( $\circ$ ), 'Galia $F_{1}$ MN-318' $(\Delta)$, and 'Galia $F_{1}$ Solar King' ( $\square$ ) cantaloupe cultivars. Vertical bars represent LSD (5\%). 
Phenolic Compounds: Phenolic compounds progressively decreased with growth and development in the three cantaloupe cultivars (Fig. 7 ). At the full ripe stage (48 DAA) the drop in total phenolics was 1.6- folds in 'Standard' and 1.7- folds in 'MN-318' and 'Solar King' cultivars. This is in agreement with Spayed and Morris (1981), who reported that phenolic compounds were relatively higher in the immature-green fruits than in the mature ones. Similar results were reported during growth and development of mango (Abu-Gooukh et al., 2005), guava (Misra and Swshadri, 1968), papaya (AbuGoukh et al., 2010), apple (Hulme, 1971) and date (Al-Ogaidi and Mutlak, 1986) and ripening of mango (Abu-Goukh and Abu-Sarra, 1993), and guava (Bashir and Abu-Goukh, 2003). Phenolic constituents are responsible for the astringent taste in unripe fruits. The decrease in astringency in fruits during ripening was associated with the increased polymerization of leucoanthocyanidins and hydrolysis of the astringent arabinose ester of hexahydrodiphenic acid (Misra and Swshadri, 1968).

Phenolic compounds have been repeatedly demonstrated to play vital roles in plant disease resistance and protect fruits and vegetables against pests (Abu-Goukh et al., 2003) and diseases (Raa, 1968). Abu-Goukh et al. (2003) found a negative correlation between phenolic compounds and insect infestation during storage of dry dates. A key role was proposed for phenolics in resistance of dates to insect infestation during storage (Al-Ogaidi and Mutlak, 1986; Abu-Goukh et al., 2003). Phenolics were reported to be higher in peel than pulp of mango (Abu-Goukh and Abu-Sarra, 1993; AbuGoukh et al., 2005) and guava (Bashir and AbuGoukh, 2003) and that was proposed to have significance in plant disease resistance in fruits.

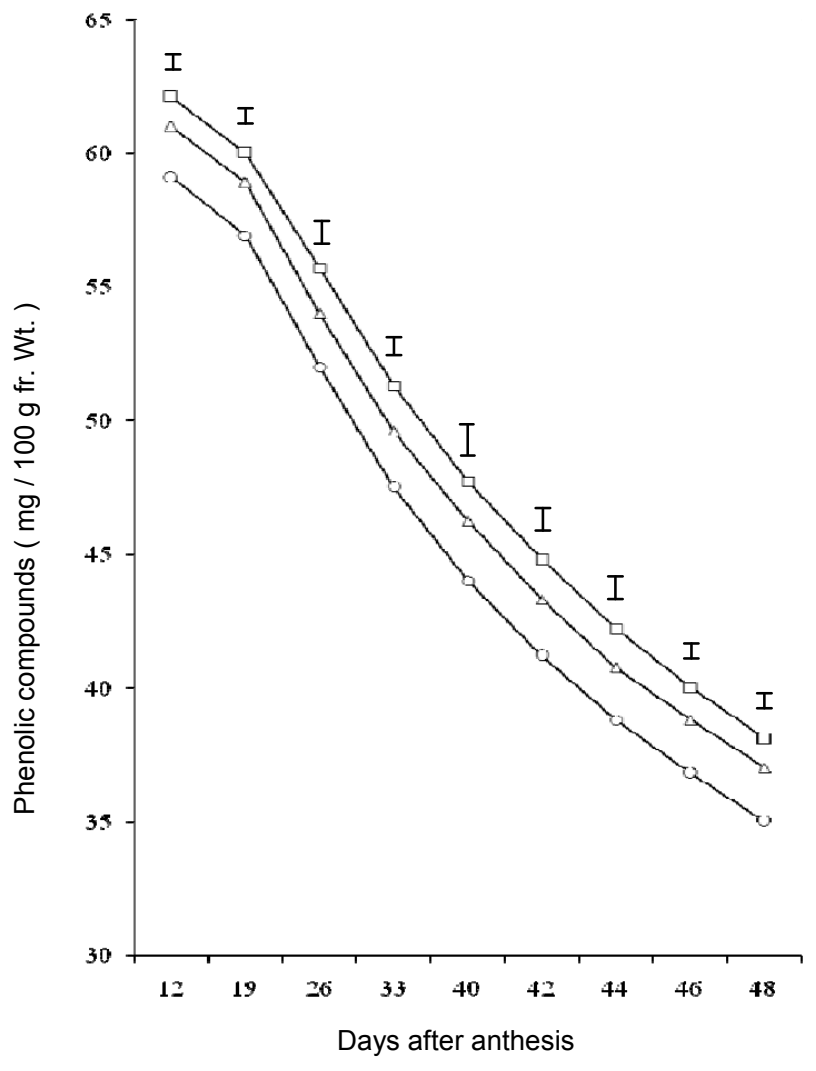

Fig. 7. Changes in Phenolic compounds during growth and development of 'Galia $F_{1}$ Standard' ( $\left.\circ\right)$, 'Galia $F_{1}$ MN-318' $(\Delta)$, and 'Galia $F_{1}$ Solar King' ( $\square$ ) cantaloupe cultivars. Vertical bars represent LSD (5 \%). 
Ascorbic Acid Content: Ascorbic acid content progressively increased in the three cantaloupe cultivars, reached a maximum at the mature-green stage (44 DAA) and then declined rapidly as the fruit ripened (Fig. 8). Similar results were reported during growth and development of guava (Agnihortri et al., 1962) and ripening of tomato (Ahmed and AbuGoukh, 2003). Ascorbic acid content steadily decreased during growth and development in mango (Abu-Goukh et al., 2005) and progressively increased during growth and development of papaya (AbuGoukh et al., 2010). 'Solar King' cultivar showed the highest ascorbic acid content of $47 \mathrm{mg} / 100 \mathrm{~g}$ at 44 days, followed by 'Standard' $(42.5 \mathrm{mg})$ and then $\mathrm{MN}$ $318(38 \mathrm{mg} / 100 \mathrm{~g})$. The amount of ascorbic acid retained at the full-ripe stage (48 DAA) was $37 \mathrm{mg}$, 32 and $30 \mathrm{mg} / 100 \mathrm{~g}$ in the three cultivars, respectively (Fig. 8).

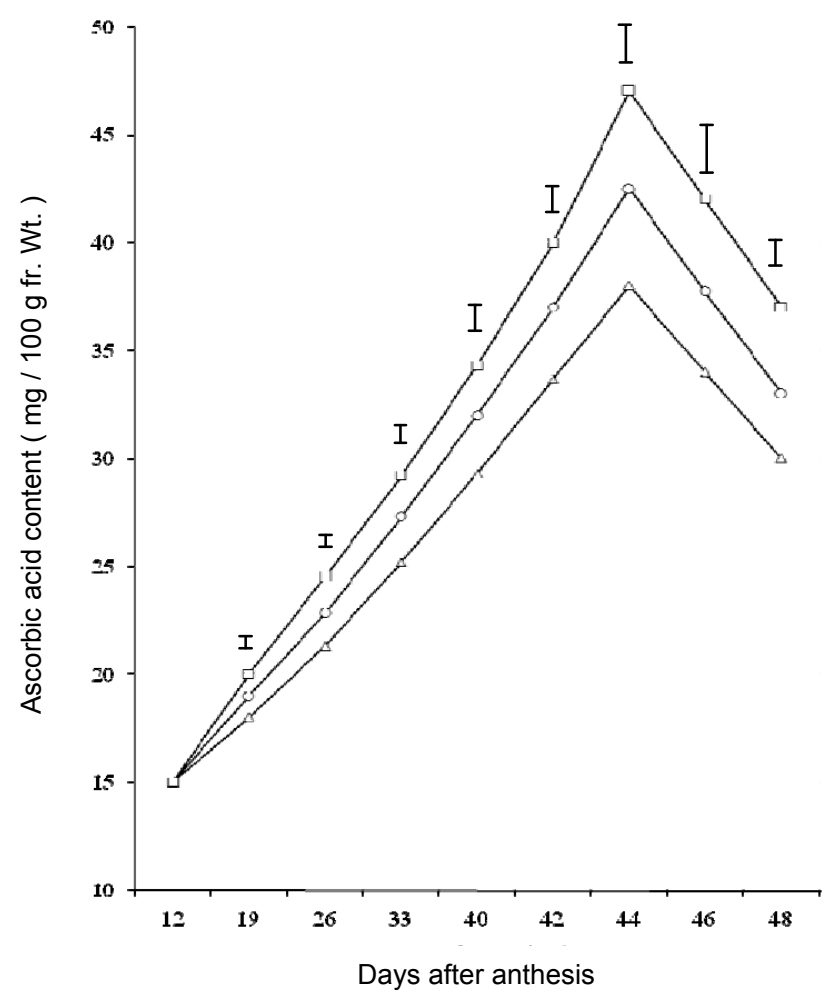

Fig. 8. Changes in ascorbic acid content during growth and development of 'Galia $F_{1}$ Standard' $(\circ)$, 'Galia $F_{1}$ MN-318' $(\Delta)$, and 'Galia $F_{1}$ Solar King' $(\square)$ cantaloupe cultivars. Vertical bars represent LSD (5\%).

\section{CONCLUSION}

Galia cantaloupes should be harvested at least at physiological maturity, where the fruit attains maximum size and weight, rind color develops, TSS reaches $10 \%$, total sugars above $8 \%$, proteins and ascorbic acid at maximum levels, titratable acidity starts to decrease, phenolics are reasonably low and the fruit is still firm.

\section{REFERENCES}

Abbas, A. M. (2004). Exportation chances for Sudanese horticultural commodities. Symposium of European Community Standards for Horticultural Commodities. Sudanese Standards and Measurements Corporation (SSMC), Khartoum, Sudan. 
Abu-Goukh, A. A. and Abu-Sarra, A. F. (1993). Compositional changes during mango fruit ripening. University of Khartoum Journal of Agricultural Sciences, 1(1): 32-51.

Abu-Goukh, A.A.; Shattir, A.E. and Mahdi, E.M. (2010). Physico-chemical changes during growth and development of papaya fruit. II. Chemical changes. Agriculture and Biology Journal of North America, 2010, 1(5): 871-877.

Abu-Goukh, A. A. and Basheir, H.A. (2003). Changes in pectic enzymes and cellulase activity during guava fruit ripening. Journal of Food Chemistry, 83(2): 213-218.

Abu-Goukh, A. A.; Mohamed, H. E. and Garray, H. E. B. (2005). Physico-chemical changes during growth and development of mango fruit. University of Khartoum Journal of Agricultural Sciences, 13(2): 179-191.

Abu-Goukh, A. A.; Shattir, A, E, and El Balla, M. M. A. (2003). Effect of harvesting method on quality and storability of dry dates in Sudan. Journal of Tropical Science, 43: 53-56.

Abu-Sarra, A. F. and Abu-Goukh, A. A. (1992). Changes in pectinesterase, polygatacturonase and cellulase activity during mango fruit ripening. Journal of Horticultural Science, 67(4): 561-568.

Agblor. S. and Waterer. D. (2001). Muskmelons Cantaloupe Post-harvest, Handling and Storage. Department of Plant Sciences, University of Saskatchewan. URL: http: //www.4.agr.gc.ca/resources/prod / doc/pfraarap/csidc/pdf/melons-e.pdf.

Agnihotri, B.N, Kapur, K.L., and Goel, K.R. (1962). Ascorbic acid content of fruits during growth and maturity. Science and Culture, 28: 435-438.

Ahmed, A. E. and Labavitch, J. M. (1980). Cell wall metabolism in ripening fruits. 11: Changes in carbohydrate-degrading enzymes in ripening 'Bartlett' pears. Plant Physiology, 65: 1014-1016.

Ahmed, I.H. and Abu- Goukh, A. A. (2003). Effect of maleic hydrazide and waxing on ripening and quality of tomato fruit. Gezira Journal of Agricultural Science, 1 (3): 59-72.

Albuquerque, B.; Lidon, C. F. ; and Barrerio, M. G. (2006). A case study on the flavor properties of melon (Cucumis melo L.) cultivars., CIRAD, EDP Sciences, 61: 333-339.

Ali, M. B. and Abu-Goukh, A. A. (2005). Changes in pectic substances and cell wall degrading enzymes during tomato fruit ripening. University of Khartoum Journal of Agricultural Sciences, 13(2): 202-223.

Al-Ogaidi, H. K. and Mutlak, H. H. (1986). The phenolic compounds of four date cultivars during maturity stages. The Date Palm Journal, 4(2): 191-196.
AOAD (2008). Arab Agricultural Statistics Yearbook. Arab Organization for Agricultural Development (AOAD), Khartoum, Sudan.

Aulenbach, B. B., and Worthington, J.T. (1974). Sensory evaluation of muskmelon: Is soluble solids content a good quality index. HortScience, 9: 136-137.

Ayub, R.; Guis, M.; Amor, M. B; Gillot, L.; Roustan, P. J.; Latche, A.; Bouzayen, M. and Pech, C. J. (1996). Expression of ACC oxidase antisense gene inhibits ripening of cantaloupe melon fruit. Nature Biotechnolog, 14: 862 - 866.

Baraka, A. M. (2004). Report on Melon Production in Sudan. Alzahra for Agricultural Commodities and Trade. P. O. Box 4326. Khartoum, Sudan.

Baraka, A.M.; Abu-Goukh, A.A. and Elballa, M.M.A. (2010). Physico-Chemical Changes during Growth and Development of 'Galia' Cantaloupes. I. Physical Changes. 00(0), 00-00.

Bashir H. A. and Abu-Goukh, A. A., (2003). Compositional changes during guava fruit reprinting. Journal of Food Chemistry, 80(4): 557-563.

Bianco, V. V. (1969). Changes in Sugar Fractions in muskmelon as a function of fruit age after pollination. M.Sc. Thesis, University of California, Davis, U.S.A.

Bianco, V. V. and Pratt H. K. (1977). Compositional changes in muskmelons during development in response to ethylene treatment. Journal of the American Society for Horticultural Science, 102: 127133.

Bradford, M. M. (1976). A rapid and sensitive method for the quantitation of microgram quantites of protein utilizing the principle of protein-dye binding. Analytical Biochemistry, 72: 248-254.

Frenkel, C., Kelin, I. and Dilley, D. R. (1968). Protein synthesis in relation to ripening of some fruits. Plant Physiology, 43: 1146-1153.

Gomez, K. A. and Gomez, A. A. (1984). Statistical Procedures for Agricultural Research. $2^{\text {nd }}$ edition. pp. 75-165. John Willey and Sons. Inc. New York.

Hulme, A. C. (1971). The mango: In: The Biochemistry of Fruits and their Products. (Hulme, A.C., Ed.). Vol. 2. pp. 233-254. Academic Press, London and New York.

Ibrahim, K. E.; Abu-Goukh, A. A. and Yusuf, K. S. (1994). Use of ethylene, acetylene and ethrel on banana fruit ripening. University of Khartoum Journal of Agricultural Sciences, 2(1): $73-92$.

Kader, A. A. (2002). Postharvest Technology of Horticultural Crops. $3^{\text {rd }}$. edition. Publication 3311. Cooperative Extension, Division of Agriculture and Natural Resource, University of California. Oakland, California, USA. 535 p. 
Kasmire, R. F.; Rappaport, L. and. May, D. (1970). Effects of 2-chloroethyl phosphonic acid on ripening of cantaloupes. Journal of the American Society for Horticultural Sciences, 95: 134-137.

Kitamura, T.; Umemoto, T.J.; Wata, and Alabamian, T. (1975). Studies on the storage of melon fruits. II. Changes of respiratory and ethylene production during ripening with reference to cultivars. Japanese Society for Horticultural Science, 44: 197-203.

MACK (1999). Marketing Report. Multiples Division European Companies (MACK). The Netherlands.

Mattoo, A. K.; Murata, T.; Pantastico, Er. B.; Chachin, K.; Ogata, K. and Phan, C. T. (1975). Chemical changes during ripening and senescence. In: Post-harvest Physiology, Handling and Utilization of Tropical and Subtropical Fruits and Vegetables. pp. 103-127. Er. B. Pantasico (Ed.). AVI Pub. Co. Inc. Connecticut, USA.

Miller, G. (2007). Cantaloupe and Honeydew Melons. Clemson Home and Garden Information Center. Clemson University, USA. Online Edition. htt:// hgic. Clemson edu / factsheets / hgic 1304.htm.

Misra, K. and. Swshadri, T.R. (1968). Chemical components of the fruit of Psidium guajava. Phytochemistry, 7: 641-645.

Mohamed-Nour, I.A. and Abu-Goukh, A.A. (2010). Effect of ethrel in aqueous solution and ethylene released from ethrel on guava fruit ripening. Agriculture and Biology Journal of North America, 2010, 1(3): 232-237.

Munasque, V. S. and Mendoza, D.J. (1991). Devlopmenal physiology and ripening behavior of 'Senorita' banana fruit. ASEAE Food Journal, 5(4): 152-157.

Mutton, L. L.; Gullis, B. R. and Balkeney, A. B. (1981). The objective definition of eating in Rocket melons (C. melo L). Science, 32: 385-391.

Osman, H. E. and Abu-Goukh, A. A. (2008). Effect of polyethylene film lining and gibberellic acid on quality and shelf-life of banana fruits. University of Khartoum Journal of Agricultural Sciences, 16(2): 242 - 261.

Phan, C. T., Pantastico, Er. B., Ogata, K. and Chachin, K. (1975). Respiration and respiratory climacteric. In: Postharvest Physiology, Handling and Utlization of Tropical and Subtropical Fruits and Vegetables. pp.86102. Er. B. Pantastico, (Ed.). AVI Publ. Co. Inc., Connecticut. U.S.A.

Raa, J. (1968). Natural Resistance of Apple Plant to Venturia inequalis. Ph.D. Thesis. University of Utrecht, U.K.
Ranganna, S. (1979). Titratable acidity. In: Manual of Analysis of Fruit and Vegetable Products. pp. 7-8. Tata McGraw Hill Pub. Co. Ltd., New Delhi, India.

Ruck, J.A. (1963). Ascorbic Acid. Canada Department of Agricultural. Publication No.1154.

Rustenburg Co. (1999). Marketing Report. Rustenburg Company. The Netherlands.

Salunkhe, D. K. and Desai, B. B. (1984). Postharvest Biotechnology of Vegetables. Vol. 2. pp.70-75 CRC Press, Inc. Boca Raton, Florida, USA. 193p.

Singleton, V. L. and Rossi, J. R. Jr. (1965). Colorimentry of total phenolics with phosphomolybodicphosphotungestic acid reagents. American Journal of Enology and Viticulture, 16(3): 144-157.

Somogyi, M. (1952). Notes on sugar determination. Journal of Biological Chemistry, 195: 19-23.

Stepansky, A.; Kovalski, I.; Schaaffer, A. A. and Treves, R. P. (1999). Variation in sugar levels and invertase activity in mature fruit representing a broad spectrum of (Cucumis melo) genotypes. Genetic Resources and Crop Evolution, 46(1): 53-62.

Ulrich, R.(1970). Organic Acids. In: The Biochemistry of Fruits and Their Products.Vol.1. pp. 89-118. A.C. Hulme (Ed.) Academic Press, London and New York.

Villanueva, M. J.; Tenorio, M. D.; Esteban, M. A. and Mendoza, M. C. (2004). Compositional changes during ripening of two cultivars of muskmelon fruits. Journal of Food Chemistry, 87: 179-185.

Wang, Y.M. (1990). Chilling Injury of Horticultural Crops. CRC Press, Boca Raton, Florida, USA. 313 p.

Watt, B.K. and Merrill, A.L. (1975). Composition of Foods. Consumer and Food Economics Institute, Agricultural Research Service, United States Department of Agriculture. Agriculture Handbook No. 8. Washington, D.C., USA.190 p.

Wills, R., McGlasson, B.; Graham, D. and Joyce, D. (1998). Postharvest: An Introduction to the Physiology and Handling of Fruit, Vegetables and Ornamentals. $4^{\text {th }}$ edition. CAB International, Wallingford Oxan, UK. 262 p.

Yemm, E. W. and Willis, A. J. (1954). The estimation of carbohydrates in plant extracts by anthrone. Biochemistry Journal, 57: 508-513. 